\title{
Budget cuts cast shadows overseas
}

\section{US agencies}

\section{count costs}

\section{of Reagan}

\section{Washington}

The Reagan Administration, stung by criticism from Western allies of budgetbased decisions to terminate or substantially withdraw from a number of international scientific projects, is taking a close look at ways in which it may be able to repair some of the damage and prevent further unnecessary friction in the future.

Of particular concern to the new Administration is that the foreign policy function of certain types of international scientific agreements - for example, a science and technology programme agreed with Spain in 1976 as part of an exchange for being allowed to place US military bases in the country - could be jeopardized if the projects are evaluated merely on the strength of their scientific merits and the vocal energy of their domestic constituency, often very small within the scientific community.

Already, Secretary of State Alexander Haig has written to Mr Reagan's budget director, David Stockman, complaining of the fact that cuts imposed either directly by the Office of Management and Budget (OMB), or indirectly by internal decision within agencies such as the Department of Energy or the National Science Foundation (NSF), have been carried out in a manner which constitutes a unilateral abrogation of international commitments.

Among the projects listed by Mr Haig which appear to have been treated in this way is the international solar polar mission, planned jointly with the European Space Agency, from which the National Aeronautics and Space Administration (NASA) has proposed withdrawing its planned spacecraft (a decision which both congressional committees and NASA officials are busy trying to reverse, perhaps through a reduced NASA commitment which would involve the European Space Agency building the two spacecraft involved). Another is the possible cancellation of national energy assessments supported by the Department of Energy and already promised by embassies in countries such as Greece, Tunisia and Venezuela.

What concerns the State Department most is that the scientific attachés of foreign embassies in Washington are telling their capitals that US promises of scientific and technical collaboration should be looked at sceptically in the future. "While budget reductions are a clear goal for this Administration, one of its principal foreign policy objectives is to render the

United States a reliable international partner,"' wrote Mr Haig - who had previously interceded with OMB to rescue foreign aid funds and NASA's Galileo mission to Jupiter, planned with heavy West German involvement - in his letter to Mr Stockman.

International collaboration in scientific programmes is seen by Washington science policy officials as falling into three categories: that carried out by individual scientists and their institutions as part of the normal process of science; that in which both sides receive the benefit of more costeffective technical knowledge; and that carried out with some broader foreign policy goal in mind.

It is the last of these three which is particularly threatened, particularly when an international treaty or bilateral agreement has been arranged through the State Department, and then handed to another agency for execution.

One major dilemma now facing the Reagan Administration, for example, is what to do about the International Institute for Applied Systems Analysis (IIASA) in Vienna. Faced with the need to make cuts of over $\$ 300$ million - almost 25 per cent - in its proposed 1982 budget by the new Administration, NSF decided to eliminate the $\$ 3$ million US contribution to IIASA for which it is at present responsible.

Unless this decision is changed by the Administration, IIASA would have to close in 1983. Scientists claim that the institute has been carrying out some useful research, even though some express doubts about its full value. However, IIASA also

\section{Anxieties of Oslo secrets trial}

\section{Stockholm}

A trial whose outcome could affect freedom of research is being held in Oslo. Two defendants are at present accused of revealing information prejudicial to Norway's security. But this is not a normal spy case: the defendants collected the information exclusively from public sources as part of a research project funded by the Norwegian Research Council for Science and the Humanities, and there is no suggestion that they intended to pass it on to any foreign power.

The two men are Nils Petter Gleditsch of the Oslo International Peace Research Institute (PRIO) and Owen Wilkes, a New Zealander formerly at PRIO and now at the Stockholm International Peace Research Institute. They maintain that freedom of research should be upheld, and that they have not in any case revealed information which could damage Norway's security. They say that what they have discovered from open sources, a foreign power (that is, the Soviet Union) could investigate in far more detail with provides an important channel for East/West communication.

Moves are therefore under way to discover whether the closure of the institute - which would anger the Austrian government considerably, since it has put a lot of money into providing facilities - can be averted. For the 1982 contribution, already committed under IIASA's constitution, NSF is working out whether it can provide money from other sources within the foundation.

Recognizing that the problems raised by the controversy over the international solar polar mission and IIASA contributions have deep roots in beliefs about the proper political role of the federal government in support for science, the State Department has set up an inter-agency committee to discuss possible guidelines for the future. Two suggestions it is likely to discuss are that OMB should be presented, early in its budget cycle, with an overall picture of overseas implications. The other is that the State Department itself might be given funds for supporting international scientific activities which it feels have important political functions, but might not generate the required support within an individual agency.

At the same time the agencies themselves are looking closely at their own policies and procedures. Few solutions are in sight, but one consolation to US scientists is that, as a result of recent events, the whole issue has been placed high on the State Department's agenda at an early stage and is already receiving close attention from what are usually described as the "top levels" of government.

David Dickson intelligence satellites. They conclude that the Norwegian government's reticence about military affairs is keeping secrets from the Norwegians themselves, not from the Russians.

The history of the case is this: Gleditsch and Wilkes published their research report, "Intelligence installations in Norway: their number, location, function and legality", in February 1979 as part of a PRIO project (still continuing) on the location and functions of military facilities in Norway. They timed the publication to coincide with another trial then being held, in which three Norwegians - a publishing house executive and two journalists who had collected the names of Norwegian secret servicemen - were accused of collecting information which could damage the country's national security. Gleditsch and Wilkes wanted to show how easy it is to obtain from open sources information considered to be very sensitive.

The prosecutor general ordered an investigation into the Gleditsch-Wilkes report, and in March 1979, the chief of 
defence staff, General Sverre Hamre, told the Norwegian police that he considered it a threat to the activities of Norwegian defence and national security. Having questioned the authors and PRIO staff closely associated with preparing the report, the police completed their investigations in June 1979 and sent preliminary charges against Gleditsch to the court. They charged him on three counts: two under the penal code revealing information which ought to be kept secret in the interests of national security relative to foreign powers, and acquiring this information or making it available to others - and one under the law on defence secrets - recording, copying, or publishing sketches of fortifications or associated installations. According to Norwegian practice, the police also appointed three independent experts to evaluate the report. The intelligence service proposed two of these (one was the former head of the service) and Gleditsch and Wilkes the third. Not surprisingly, the experts nominated by the intelligence service supported General Hamre's opinion that the report threatened national security. The formal indictment charges Wilkes as well as Gleditsch with all three charges, which carry a maximum penalty of $4 \frac{1}{2}$ years imprisonment.

The technical intelligence facilities described in the Gleditsch-Wilkes report collect and analyse data from electronic intelligence satellites, monitor and analyse military and diplomatic radio signals, and intercept and interpret electronic and telemetric communications. Although the authorities are traditionally tight-lipped about such installations, the authors point out that it was very easy to find out about them by using, for example, the ordinary telephone directory and public lists of government-owned property. They also learned a lot by observing the installation's antennas: their size, shape and layout. The authors maintain that if the Soviet Union, with its sophisticated spy satellites and, presumably, other more traditional techniques of spying, is interested in the installations, it would already know a great deal about Norwegian security. They claim that the authorities' secrecy is mainly directed towards the Norwegian population itself, pointing to police reaction to the publication of their report in Norwegian, shortly before the trial began. For two years the report has been available in English and the police have made no attempt to confiscate it; however, they have now declared the publication of the Norwegian translation illegal.

Support for Gleditsch and Wilkes has come from the International Peace Research Association, the Norwegian Writers' Union and political youth organizations in Norway. The trial is expected to last for another week or so, and the verdict will follow a couple of weeks after that. One or both sides will almost certainly appeal.

\section{UK nuclear power \\ Plans panned}

For the second time this year, Britain's Central Electricity Generating Board (CEGB) has received a rap over the knuckles for not providing enough information about the economic case for its planned nuclear power programme. Hard on the heels of sharp criticism from the House of Commons Select Committee on Energy last March, the Monopolies and Mergers Commission last week published a report on the board's finances (HC 315, HMSO, £9.30). The Monopolies Commission was asked to find out whether CEGB is charging a fair price for the electricity which it supplies to the consumer through regional electricity boards.

The commission says that one of the chief reasons for the high cost of electricity in Britain is CEGB's previous tendency to invest in new plant before strictly necessary. Decisions to order new plant, it concluded, have often been based on over-

\section{Gloom on research}

A high-level meeting of research councils from Germany, France, the United Kingdom and the United States was held in the English country town of Abingdon on the weekend of 16-17 May. The occasion, arranged by Sir Geoffrey Allen, chairman of the British Science and Engineering Research Council, is the second in a series of consultations begun with a meeting called by Professor H. R. Leibnitz, then the president of the Deutsche Forschung Gemeinschaft in June last year.

The objective appears to have been an exchange of views, most of them gloomy. The United States participants (Dr John Slaughter and Dr H. R. Langenberg, respectively director and deputy director of the National Science Foundation) left their fellow-administrators with the impression that the Reagan budget had been a body blow whose effects will not be confined to the United States, but that the United States is also worried by more long-standing problems - the difficulty of recruiting teachers of engineering for United States universities, for example.

European participants in the meeting are said to have welcomed their transatlantic colleagues into the company of the impoverished, and to have urged that if the United States now faces a period of entrenchment it would be worthwhile thinking of collaboration with European collaborative ventures such as those at CERN. The occasion seems also to have been one for concerted European complaint about the budgetary threat to the solar polar mission, the plan to send two spacecraft (one European, one American) into polar orbits about the Sun. estimates of future demand, and economic cases have been made on over-optimistic estimates of construction times, capital costs and the ultimate performance of power stations.

The commission's report is particularly critical of the decision, to build the second advanced gas-cooled reactor at Heysham, taken in 1979 as part of the government's decision to embark on a further nuclear programme, probably based on the Westinghouse design of the pressurized water reactor. Failing approval at next year's public inquiry, CEGB hopes to keep open the option of basing the programme on the notoriously costly British-designed AGR by building Heysham II.

Although the commission acknowledges that CEGB has learnt from its previous mistakes with the AGR, it still criticizes the board for not providing sufficiently detailed cost estimates for Heysham II, even though the decision to build it was taken largely on strategic grounds.

The commission also faults CEGB's case for future nuclear power stations on economic grounds. It says that the board's estimate of net effective cost assumes unrealistic improvements in future construction time and operational performance. Margins of error in cost estimates, together with a better indication of the board's assumptions, should have been presented to the government when making an economic case for the nuclear programme. The board should also have compared the cost of building new nuclear stations with the cost of refurbishing old coal-fired stations.

The commission, however, has praised the way in which CEGB keeps a check on its current expenditure and seems to be impressed with the performance of its Barnwood division, unpopular with many of its contractors, in keeping a detailed check on cost increases during construction. The commission's report, however, ends on a rather gloomy note. Even if CEGB implements all its recommendations, the commission cannot foresee any substantial cut in electricity prices to the consumer. Judy Redfearn

\section{US science funding}

\section{Rewards of genius}

\section{Washington}

Acting on the theory that intellectual and cultural breakthroughs can be accelerated if latent genius is permitted to flourish free of the more material considerations of making a daily living, one of the newest and wealthiest - foundations in America has announced the first of a series of fiveyear, no-strings-attached awards to "exceptionally talented" individuals.

The awards are being made by the trustees of the John D. and Catherine MacArthur Foundation set up two years ago from the estate of the late Chicago insurance and real estate millionaire. The 